\title{
Influence of Different Normalizing Processes on Mechanical Properties and Microstructure of AISI 4140 Alloy Steel
}

\author{
Yusuf YILMAZ, Ethem KEST I \\ Konya Technical University, Faculty of Eng. \& Natural Sciences, Department of Mechanical Engineering Konya, Turkey \\ yyilmaz@ktun.edu.tr \\ ethemkesti@hotmail.com
}

\begin{abstract}
In this study, the effect of the normalization process on the mechanical properties of AISI 4140 alloysteel and the changes in the microstructure of the material were investigated experimentally. For this study, test samples were prepared from AISI 4140 alloysteel. These test samples were collected in 2 groups. While no heat treatment was applied to one of these groups, the other group was only subjected to Normalization. The changes in the mechanical properties and microstructures of the untreated and normalized samples were investigated.
\end{abstract}

Keywords: Steel, Quenching, Tempering, Tensile Test, Impact Test, Microstructure

\section{Introduction}

AISI 4140 alloy steels are widely used in the machinery manufacturing industry. For example, AISI 4140 alloy machine-building steel is used at a rate of $10 \%$ in the machining industry and is a steel with high hardenability due to the alloying elements it contains (MKE, 1993).The most important feature of AISI 4140 alloy steel is that it can form a hard martensitic structure after quenching due to the $\mathrm{Cr}$ and Mo alloying elements it contains, allowing mechanical properties such as strength, ductility, and toughness to be provided together. For all these reasons, AISI 4140 alloy steel is always common steel. (Avner, 1986; Choo et al., 2000). The brittleness that may occur during tempering at specific temperature values in most machine elements is one of its biggest disadvantages (Oliveira et al., 2000). In order to prevent this negative effect, it is very important to choose the appropriate temper temperature (Charre, 2004; Buytoz, 2004). Therefore, it is necessary to determine the properties of AISI 4140 alloy steel after tempering.

\section{Normalization}

The main purposes of normalization annealing are;

a) grain reduction,

b) To obtain a homogeneous internal structure,

c) To distribute the carbide network at the grain boundaries in supraeutectoid steels,

d) To improve the processing properties of steels,

e) Improving mechanical properties

f) To increase the hardness and strength of steels subjected to softening annealing.

The waiting time at the normalization level should not be long as it will cause grain growth. In Table 1, normalization times are given according to the thickness of the material to be annealed.
Table 1: Normalization heat treatment times according to part thickness (Töre, 2007)

\begin{tabular}{|c|c|c|c|}
\hline $\begin{array}{c}\text { Part thickness } \\
(\mathrm{mm})\end{array}$ & Heating Time (min) & $\begin{array}{c}\text { Waiting Time at } \\
\text { Norm. Temp. (min.) }\end{array}$ \\
\hline $\mathrm{T} \leq 6$ & 20 & 10 & 15 \\
\hline $6.1 \leq \mathrm{T} \leq 12$ & 30 & 10 & 25 \\
\hline $12.1 \leq \mathrm{T} \leq 25$ & 45 & 10 & 30 \\
\hline $25.1 \leq \mathrm{T} \leq 38$ & 60 & 15 & 30 \\
\hline $38.1 \leq \mathrm{T} \leq 50$ & 75 & 20 & 30 \\
\hline $50.1 \leq \mathrm{T} \leq 63$ & 90 & 25 & 40 \\
\hline $63.1 \leq \mathrm{T} \leq 75$ & 105 & 30 & 45 \\
\hline $75.1 \leq \mathrm{T} \leq 90$ & 120 & 35 & 55 \\
\hline $90.1 \leq \mathrm{T} \leq 100$ & 135 & 40 & 60 \\
\hline $100.1 \leq \mathrm{T} \leq 125$ & 165 & 50 & 75 \\
\hline $125.1 \leq \mathrm{T} \leq 150$ & 195 & 60 & 90 \\
\hline $150.1 \leq \mathrm{T} \leq 180$ & 225 & 75 & 105 \\
\hline $180.1 \leq \mathrm{T} \leq 200$ & 225 & 90 & 120 \\
\hline
\end{tabular}

\section{Experiments}

\subsection{Specimen Material}

Rolled low alloy AISI 4140 alloy steel was used in this experiment. Chemical analyzes were carried out in the laboratory of Eti Aluminum A.Ş., Quality Control and R\&D Department, using the ARL ADVANT'X XFR spectrometer device. Its chemical analysis is given in Table 2.

Table 2: Chemical composition of AISI 4140 alloysteel \begin{tabular}{|l|l|l|l|l|l|l|l|l|l|}
\hline Material & $\% \mathrm{C}$ & $\% \mathrm{Si}$ & $\% \mathrm{Mn}$ & $\% \mathrm{~S}$ & $\% \mathrm{P}$ & $\% \mathrm{Cr}$ & $\% \mathrm{Mo}$ & $\% \mathrm{Ni}$ \\
\hline
\end{tabular} \begin{tabular}{|c|c|c|c|c|c|c|c|c|}
\hline Ç-4140 & 0,450 & 0,340 & 0,790 & 0,020 & 0,023 & 0,860 & 0,155 & 0,090 \\
\hline
\end{tabular}

\subsection{Experiments}

While 3 of the 6 test samples prepared were subjected to the normalization process, no treatment was applied to the other 3 samples.

\subsection{Normalization process}

A resistance heat treatment furnace was used in these experiments. Two test samples were subjected to the 
normalization process. The temperature required for normalization was determined as $870^{\circ} \mathrm{C}$ from the iron carbon balance diagram. The samples were placed in the furnace and the furnace was started. When the oven temperature reached $870^{\circ} \mathrm{C}$, the test samples were kept in the oven for 25 minutes and left to cool in still air.

\section{Results}

\subsection{Effect of Normalization Process on Mechanical Properties}

With the normalization process, the microstructure of the material is transformed from coarse pearlite to fine pearlite. This change increases the tensile and yield strength of the steel. This causes a decrease in elongation at break, narrowing of the section and impact strength. Table 3 shows the untreated AISI 4140 alloy steels and the mechanical properties of these steels as a result of the normalization process. Table 4 and Table 5 are compared with other studies.

Table 3: Mechanical properties of untreated and normalized AISI 4140 alloy steels

\begin{tabular}{|c|c|c|}
\hline Compared properties & Untreated & Normalized \\
\hline Hardness (HRC) & 20 & 26 \\
\hline Tensile Strength (N/mm²) & 992 & 1078 \\
\hline Yield Strength (N/mm²) & 723 & 721 \\
\hline Elongation (\%) & 14 & 11 \\
\hline Reduction in cross section (\%) & 33 & 22 \\
\hline Impact Resistance (Joule) & 46 & 21 \\
\hline
\end{tabular}

Table 4: Comparison of mechanical properties of untreated AISI 4140 alloysteels with other studies

\begin{tabular}{|c|c|c|c|}
\hline Compared properties & $\begin{array}{c}\text { Our } \\
\text { Study }\end{array}$ & $\begin{array}{c}\text { ASME } \\
\text { Handbook }\end{array}$ & $\begin{array}{c}\text { Turhan } \\
\text { Çökelek (2001) }\end{array}$ \\
\hline Hardness (HRC) & 20 & 20 & 26 \\
\hline Tensile Strength(N/mm²) & 992 & 655 & 600 \\
\hline Yield Strength(N/mm²) & 723 & 420 & 500 \\
\hline Impact Resistance(Joule) & 46 & 54 & ---- \\
\hline
\end{tabular}

Table 5: Comparison of mechanical properties of normalized AISI 4140 alloy steels with other studies

\begin{tabular}{|c|c|c|c|}
\hline Compared properties & $\begin{array}{c}\text { Our } \\
\text { Study }\end{array}$ & $\begin{array}{c}\text { ASME } \\
\text { Handbook }\end{array}$ & $\begin{array}{c}\text { Turhan, } \\
\text { Çökelek (2001) }\end{array}$ \\
\hline Hardness (HRC) & 26 & 30 & ---- \\
\hline Tensile Strength (N/mm²) & 1078 & 1020 & 1000 \\
\hline Yield Strength (N/mm²) & 721 & 655 & 950 \\
\hline Impact Resistance (Joule) & 21 & 23 & ---- \\
\hline
\end{tabular}

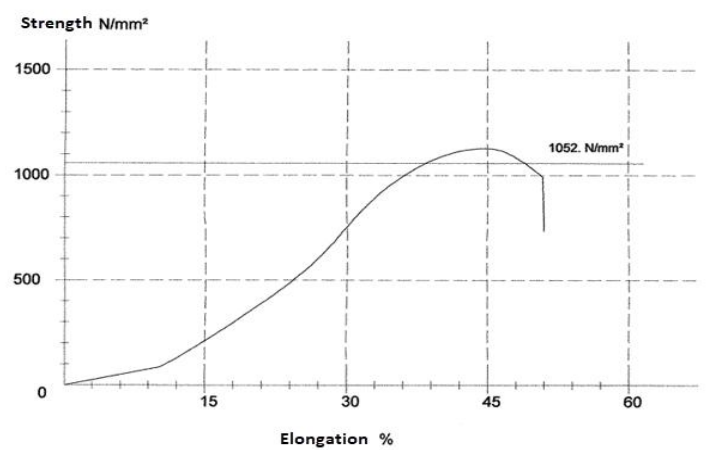

Figure 1: Tensile diagram of untreated AISI 4140 alloy steel

\subsection{Effect of Normalization Process on Microstructure}

The microstructure of the untreated steel is shown in Figure 2, The microstructure formed as a result of the normalization process is shown in Figure 3. The microstructure of the normalized steel is in the form of ferrite + perlite. The white regions are ferrite and the black regions are pearlite. The structure is in a more homogeneous distribution than untreated steel.

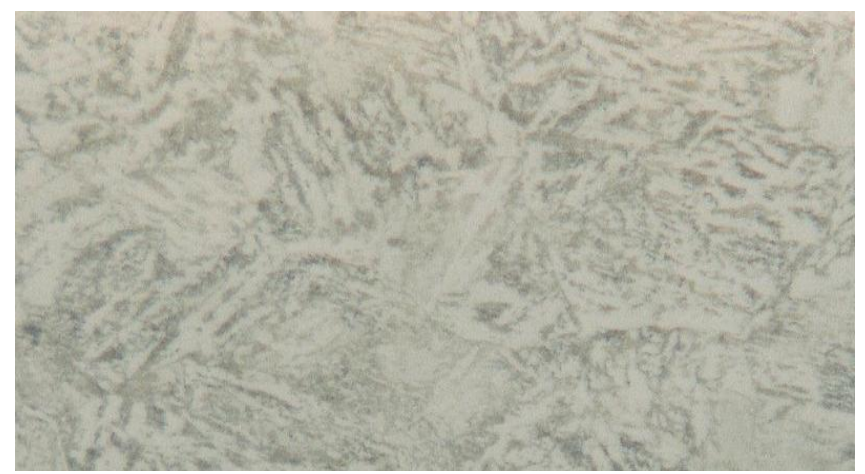

Figure 2: Microstructure of untreated AISI 4140 alloy steel $(500 X)$

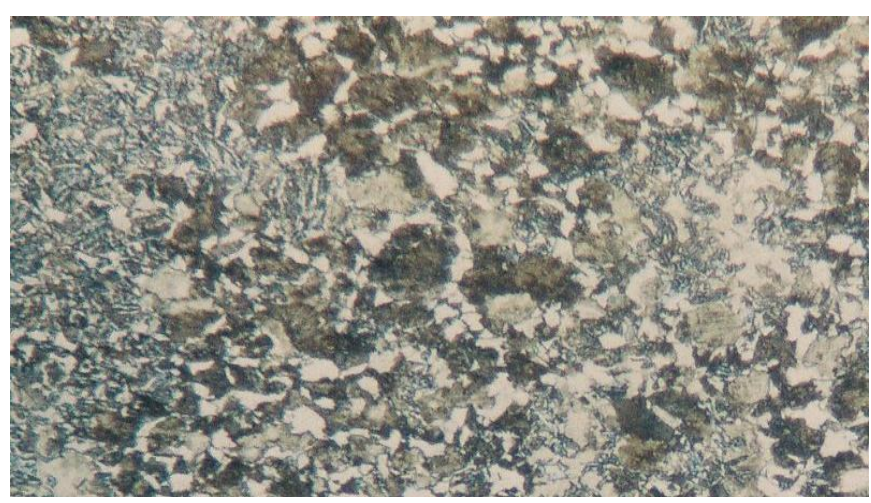

Figure 3: Microstructure of Normalized AISI 4140 alloy steel $(500 \mathrm{X})$

\section{Conclusion}

An increase in the mechanical properties of the material was observed with the normalization process. And also an increase was observed in tensile and yield strengths due to the thinning of the perlite structure in the microstructure. On the other hand, the impact strength decreased due to the thinning of the grain structure.In the microstructure photographs, it was observed that a homogeneous structure was formed in the material with normalization.

\section{References}

[1] ASM Metals Handbook, 1997. Volume 1, Properties and Selection, Iron, Steel andHighPerformance Alloys, Tenth Edition, Fifth Printing, Materials Park, Ohio, USA, $1063 \mathrm{~s}$.

[2] Ashby, M. F. and Jones, D.R.H., 1998, EngineeringMaterials,2nd ed., Oxford, UK: Butterworth-Heinemann, 125-132 p., (vol. 1). 322p, (vol. 2). $392 \mathrm{~s}$ 
[3] Avner, S.H., 1986, Introduction to Physical Metallurgy, McGraw Hill Book Company, 2.ed., New York, 315336.

[4] Buytoz, S., 2006, Microstructural properties of M7C3 eutectic carbides in a $\mathrm{Fe}-\mathrm{Cr}-\mathrm{C}$ alloy, Materials Letters, 60, 605-608 s.

[5] Çökelek M., 2001, IslahÇeliklerinde, Isılİşlem Parametrelerinin YorulmaLimitineEtkisi, YüksekLisansTezi, SüleymanDemirelÜniversitesi, Fen BilimleriEnstitüsü, Isparta

[6] Charre, M. D., 2004, Microstructure of steel and cast irons, (Trans. J.H. Davidson), Springer-Verlag Berlin Heidelberg New York 2004, 417 s.

[7] Cheremisinoff, N. P., 1996, Materialsselection desk book (pdf form-CRC press), Noyes Publications Westwood, New Jersey, U.S.A, 191 s.

[8] Choo, S., Lee, S. and Golkovski, M. G., 2000, Effects of accelerated electron beam irradiation on surface hardening and fatigue properties in an Ç-4140 steel used for automotive crankshaft, Materials Science and Engineering A293, 56-70 s.

[9] Chuang J. H., Tsay L. W. and Chen C., 1998, Crack growth behavior of heat- treated 4140 steel in air and gaseous hydrogen, International Journal of Fatigue, Volume 20, Issue 7, Pages 531-536

[10] Davis, J.R., Metals Handbook. 1990: ASM International. p. 197-199, 203 s.

[11] Krauss, G., 1997. Steel; Heat Treatment and Processing Principles, Materials Park, Ohio, 548 s.

[12] KuncR.,andPrebil I., 2003, Low-cycle fatigue properties of steel $42 \mathrm{CrMo} 4$, Materials Science and Engineering A, Volume 345, Issues 1-2, Pages 278-285

\section{Author Profile}

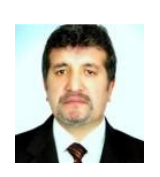

Yusuf YILMAZ was born in 1960 in Konya. He completed his primary education in Konya. Then he graduated from METU, Mechanical Engineering Department in 1985. He received his master's and doctorate degrees from Selcuk University, Institute of Science. He is still working as a lecturer and Academic Stuff at Konya Technical University. 